\title{
Regional Development of Small Firms in Poland
}

\author{
By \\ Subrata Ghatak, Kingston University \\ Alan Mulhern, Kingston University \\ Chris Stewart, London Metropolitan University
}

Address for correspondence

\author{
Alan Mulhern, \\ School of Economics, \\ Kingston University, \\ Penrhyn Road, \\ Kingston Upon Thames \\ KT1 2EE. UK \\ Tel 02083476910 \\ e-mail. A.Mulhern@Kingston.ac.uk \\ Fax 442085477388
}




\title{
Regional Development of Small Firms in Poland ${ }^{1}$
}

\begin{abstract}
Employing a probit, logit and gompit model this paper demonstrates that small firm development, represented by a group of structural, behavioral and performance variables determines regional location in Poland. The paper uses original data that samples the small firm stratum in two contrasting regions, Pomorskie and Lubelskie. The following variables were shown to be significantly correlated with regional location: legal structure, subcontracting, technological level of the products of the firm, average wage and intention to expand turnover.
\end{abstract}

JEL classification: C22, C52, L00, P27

Key Words: Polish small firms; regional polarities, location choice, probit/logit/gompit model.

\footnotetext{
${ }^{1}$ Thanks are due to an anonymous referee who provided valuable points leading to clarification of the paper.
} 


\section{Introduction}

The aim of this paper is to explore the relationship between characteristics of small firms and regional location in Poland. The paper will examine whether small firm development, represented by a range of structural, behavioral and performance variables, determines their regional location. The context for this study is the impressive growth of Polish GDP in the early 1990s that was driven by small firms and accompanied by growing regional disparities in the lead up to EU accession. By the end of the decade, however, growth had declined and unemployment increased. Pronounced regional variations in the health of the Polish labour market became apparent. Regional and small firm policy became more prominent and were put forward as possible parts of the solution to the macroeconomic slowdown. Entry into the EU accentuated this concern since European employment strategy placed policy emphasis on full employment, productivity, entrepreneurship and the alleviation of regional disparities. The surveys upon which this paper are based were carried out in 1999. This was a pre-accession period since it was widely believed at this time in Poland that accession was imminent and also since the macroeconomic development of the 1990s was thought of as preparation for this event.

This paper will examine the relationship between a range of variables illustrating small firm development and regional location. Econometric analysis of the determination of regional location by structural, behavioral and performance features of small firms in a transitional economy is unknown to the authors. These features refer to variables such as the legal form of a firm, its capacity for networking, subcontracting, technological capacity, level of human capital, intention to expand output and the like - a full list of the variables investigated is given in Table 4.

The structure of this paper is as follows. Section 2 gives the theoretical context for the paper. Section 3 gives the empirical analysis. Section 4 discusses the significant determinants of regional location. Section 5 discusses policy and theory implications. Section 6 concludes.

\section{Theoretical Context, Key Literature and Background Information.}

The theoretical context of this paper lies in cumulative growth theory, which gives a framework for understanding regional growth variations and how this might relate to the structure, behavior and performance of firms. Cumulative growth theory indicates that more developed regions, initially propelled by resource, historical or geographic advantages, produce a more competitive environment. As a result of the greater levels of demand for their products and services, greater output is generated thus creating higher levels of urbanization and industrialization. Agglomeration advantages and greater productivity result in these regions. Regional output growth, especially in the form of exports, causes cumulative growth and regional polarities through its effect on labour productivity (Kaldor 1970, Dixon and Thirlwall 1975). The Verdoorn Law, indicating the correlation between productivity growth and output of the previous period, covers a variety of complex processes (e.g. specialization of labour and technical advances) by 
which output growth in a region triggers subsequent productivity growth, which in turn triggers greater output growth. ${ }^{2}$ Such a view also has its roots in growth pole theorists (Myrdal 1957, Hirschman 1958) who have stressed not only internal economies of scale but rather external economies as underlying productivity advances and firm growth. In this scenario external economies (urbanization and localization economies) generate greater productivity advances in those regions possessing them. This in turn leads to greater growth, higher levels of urbanization and industrialization which subsequently generates higher productivity growth. ${ }^{3}$

In the above classic cumulative causation model price competitiveness is linked with increased productivity, increased output and aggregate demand in a circular process. Later models (e.g. Amable, 1992, De Benedictis, 1998) modified the proposition that this necessarily led to increasing regional polarities and pointed out that catch-up effects were also possible. Of particular importance to this paper is their introduction of non-price competitive behaviour which is believed to influence the productivity and aggregate demand of the region. ${ }^{4}$ This paper will examine a range of non-price variables that we believe influence the competitiveness of small firms (indeed of all firms and therefore of regions themselves). These include structural features of the firm, e.g. its legal structure, and ownership of other companies in Poland or abroad; behavioural features of the firm, e.g. subcontracting, exporting, and franchising; and performance features of the firm, e.g. technological and organizational improvement, investment, wages, human capital, intention to expand output, profit levels and the like.

Our basic hypothesis, which to the best of our knowledge has not been tested before, is that more developed firms "choose" the more dynamic region to locate in. This not only applies to incoming new firms into a region but to newly emerging firms and to existing firms within a region. They all have "choice" in where to locate or continue locating their operations. By a more "developed firm" we imply a range of structural, performance and conduct features already outlined and given more detail later. By a more "dynamic region" we imply a region with higher GDP per capita, greater productivity, agglomeration economies, faster growth and higher profits - all of which tend to be possessed by the faster growing regions. The reason why developed firms "choose" such regions is easily understood from a straightforward understanding of their aims which include profit maximisation, profit targets, market share, sales revenue maximisation, growth of the size of the firm and indeed plain survival. Firms, be they large or small, are more likely, on average, to achieve these aims as they qualitatively improve their performance and their organization (Penrose 1959) within a growing region. From this perspective a firm, for example, with greater productivity than the average, with more highly developed networking or subcontracting experience, with higher technological

\footnotetext{
${ }^{2}$ Empirical research has given mixed results but a recent econometric study (Fingleton and McCombie, 1998) of $178 \mathrm{EU}$ regions endorsed this "law" which is dependent on the existence of increasing returns to scale as essential to productivity growth.

${ }^{3}$ Evidence for such economies and their impact on productivity is available, for example with respect to India see Mitra (2002).

${ }^{4}$ Relevant in this respect is the view of Learning Theory which highlights the centrality of qualitative factors such learning, innovation, human capital, competitive characteristic of the market etc. as important explanations for the growth of firms (Jovasnovic 1982).
} 
functioning, higher productivity and past profits and with greater intention to expand is more likely to achieve the above aims, (be they of profit, sales, growth or survival) and inclined to "choose" the more dynamic region.

Key literature with respect to Polish small firms includes the following. For general investigation into the state of Polish small firms and their pre-accession competitiveness Piasecki et al (2000), Smallbone (1996 and 2001), and Dzierzanowski and Stachowiak (2001) give a picture of a dynamic but comparatively uncompetitive small firm stratum. Its comparative disadvantages with regard to EU rivals evident. Recommendations for the small firm stratum are made in this literature. Material concerning the growing regional polarisation of Polish space can be found again in Dzierzanowski and Stachowiak (2001) and Piasecki et al. (2000) and reference to a division within the country, Poland A and Poland B, into which the two regions of our study fall, is made. Some work (Dzierzanowski and Stachowiak 2001) has even pointed to a quantitative relationship: that for example, the numbers of small firms and their density is greater in more developed regions. Interesting policy discussion is also provided by Piasecka and Rainnie (2000) and Woodward (2001) while for literature as to how different regions and their innovation systems relate to the dynamism and competitiveness of firms see Braczyk (1998). Key articles on small firms in the Pomorskie and Lubelskie regions include Ghatak et al. (2001,2003), Mulhern (2003) and Szreder (2001). The current paper inserts itself into this literature by continuing to address the ongoing theme of the comparatively less competitive Polish small firm stratum and the growing awareness of regional differences. Our paper highlights this growing regional polarization and uniquely links this to small firm development differences. None of the above literature econometrically tests for the relationships between variables indicating small firm development and regional location - the object of this paper.

We have chosen two regions representative of the more developed and less developed parts of Poland ${ }^{5}$ - Pomorski (capital Gdansk) and Lubelskie (capital Lublin) - and have sampled a range of small firms' structural, behavior and performance characteristics in both. We test our hypothesis by using binary choice models (probit, logit and gompit) to examine the determination of regional location by such small firm features. The faster growing and more developed region (in terms of GDP per capita) is expected to have firms that possess a more developed range of structural, behavioral and performance features compared to firms in the less developed and slower growing region.

As part of the background to this paper we now present briefly the information on differences between our representative regions. Fig. 1 shows a $30 \%$ difference between the per capita GDPs of Pomorskie and Lubelskie at the start of 1995. By 2000 this had widened to $46 \%$. Pomorskie (the Gdansk region) is more favoured than Lubelskie particularly in its geographical location - bordering the Baltic and closer to the expanding economic space of Germany and the EU. Lubelskie is an eastern region with most of its exports going east to Russia and the Ukraine. The per capita GDP of the two regions

\footnotetext{
${ }^{5}$ These two groups of regions have been referred to as Poland A and B. The regions of Pomorskie and Lubelskie are part of the sample suggested by Piasecki et al. (2000) as representative of Poland A and B. Berger et al (1998) also note these structural differences in the Polish space.
} 
shows a higher level for Pomorskie, as well as a faster growth rate. Despite having the same population numbers (2.2.million) industrialization and urbanization are at higher levels in the Pomorskie region which had, in 1999, an industrial output $120 \%$ larger than that of Lubelskie's. ${ }^{6}$ Pomorskie also had $68.8 \%$ of its population urbanized compared to Lubelskie's 48.2\%. As expected the consequent urbanization and agglomeration economies result in greater productivity advantages. Pomorskie had a $40 \%$ industrial productivity advantage over Lubelskie. There was a 20\% difference (2001) between wage levels in the private sector of their industries. The GDP per capita trends of a wider set of regions representing Poland $\mathrm{A}$ and $\mathrm{B}$ (faster and slower growing regions) are illustrated in Fig. 2 which shows a 30\% difference between the averaged GDP per capita of select regions in 1995 widening to $40 \%$ by 2000 . Regional polarities have been widening in Poland. Pomorskie and Lubelskie are representative of this division. ${ }^{7}$

We now turn to the empirical specification of the model.

\section{Empirical Analysis}

In this section we outline the empirical modelling of regional differences in Poland. First we discuss the econometric method to be employed for inference followed by a discussion of the data and then we present and interpret the estimation results.

\subsection{Econometric methodology}

The dependent variable (denoted $\mathrm{Y}_{\mathrm{i}}$ ) that we model is dichotomous, taking the value of zero for firms in the Polish region of Lubelskie $\left(Y_{i}=0\right)$ and unity for those in Pomorskie $\left(Y_{i}=1\right)$. The appropriate specification to employ in these circumstances is a binary choice model including the standard probit, logit and gompit models because these are specifically designed for equations where the dependent variable has two categories. Since there is no theoretical reason for favouring, for example, the probit over the logit form (or vice versa) and there is typically little difference in the results obtained from the two forms (Greene, 2000, p. 815) we focus on the probit model.

Following the discussion above we hypothesise that a range of factors (denoted by the matrix $\mathbf{X}$ ), including economic characteristics, can be used to determine regional location. The probit model specifies the probability that $\mathrm{Y}_{\mathrm{i}}$ takes on any particular value, $\mathrm{Y}$, (denoted as $\operatorname{Pr}\left[\mathrm{Y}_{\mathrm{i}}=\mathrm{Y}\right]$ ) as:

\section{$\mathbf{X} \beta$}

\footnotetext{
${ }^{6}$ Pomorskie's industry supplied $5.9 \%$ of GNP while Lubelskie's supplied $2.7 \%$. This and the following statisitics in this paragraph are taken or calculated from: Polska Statystyka Publiczn: http://www.stat.gov.pl/english.

${ }^{7}$ The Polish Agency for Enterprise Development (2001 p63 ) reported .."In 1999 the division of the country into the so-called Poland "A" and "B", i.e. western and eastern Poland, became even more distinct. This negative trend is a cause for concern, the more so, if one takes into account the high rate of unemployment and the low level of economic development of most of the voivodships in eastern Poland".
} 
$\operatorname{Pr}\left[Y_{\mathrm{i}}=1\right]=\Phi(\mathbf{X} \boldsymbol{\beta})=\int_{-\infty} \phi(\mathrm{s}) \mathrm{ds}$

$\operatorname{Pr}\left[Y_{i}=0\right]=1-\Phi(\mathbf{X} \boldsymbol{\beta})=1-\int_{-\infty}^{\mathbf{X} \boldsymbol{\beta}} \phi(\mathrm{s}) \mathrm{ds}$

where $\boldsymbol{\beta}$ is the vector of coefficients corresponding to $\mathbf{X}, \phi(\bullet)$ denotes the non-cumulated (normal) distribution and $\Phi(\bullet)$ is the cumulative (normal) distribution. ${ }^{8}$ Using the normal distribution the probit model transforms the values of $\mathbf{X} \boldsymbol{\beta}$, that are defined over the infinite interval $(-\infty<\mathbf{X} \boldsymbol{\beta}<\infty)$, into probabilities that are weakly bounded by zero and one $\left(0 \leq \operatorname{Pr}\left[\mathrm{Y}_{\mathrm{i}}=\mathrm{Y}\right] \leq 1\right)$. Thus, all probabilities take on sensible values and variances cannot be negative.

The probability model for the probit specification, given equation (3.1a) and (3.1b), is (where $\mathbf{y}$ is the vector representation of the observations on the dependent variable $\mathrm{Y}_{\mathrm{i}}$ ):

$\mathrm{E}(\mathbf{y} \mid \mathbf{X})=\sum_{\mathrm{Yi}=0}^{1}\left\{\mathrm{Y}_{\mathrm{i}} \times \operatorname{Pr}\left[\mathrm{Y}_{\mathrm{i}}\right]\right\}=\Phi(\mathbf{X} \boldsymbol{\beta})$

The parameters of this model, as with any non-linear specification, do not necessarily yield the marginal effects [Greene (2000) p. 815]. For the probit model the marginal effects are obtained from the following expression: ${ }^{9}$

$\partial \mathrm{E}(\mathbf{y} \mid \mathbf{X}) / \partial \mathbf{X}=\partial \Phi(\mathbf{X} \boldsymbol{\beta}) / \partial \mathbf{X}=\phi(\mathbf{X} \boldsymbol{\beta}) \boldsymbol{\beta}$

\subsection{Data and Variables}

Our analysis is based on original primary survey data obtained by direct interviews via a detailed questionnaire in the small firm stratum of Pomorskie and Lubelskie in 1999. They were part of a research programme "An Empirical Study of Small and Medium Size Enterprises in Poland: Phase $11 " .{ }^{10}$ Small firms were defined as employing between 10 and 49 employees $^{11}$ and the sectors of manufacture, trade, construction, transport and

\footnotetext{
${ }^{8}$ For the probit model one employs the normal distribution thus: $\int \phi(s) d s=[1 / \sqrt{ }(2 \pi)] \int \exp \left\{-1 / 2 \mathrm{~s}^{2}\right\} \mathrm{ds}$. A different distribution is used for the logit form [and, indeed, the gompit (extreme value) form].

${ }^{9}$ Strictly this expression is only correct when the explanatory variable of interest is continuous. However, "taking the derivative with respect to the binary variable as if it were continuous provides an approximation that is often surprisingly accurate" (Greene (2000) p. 817). Given this expression the marginal effect of a particular variable is typically calculated in one of two ways. First, one can evaluate $\phi(\mathbf{X} \boldsymbol{\beta})$ in (3.3) using the sample means of the explanatory variables and multiply the result by $\boldsymbol{\beta}$. Second, $\phi(\mathbf{X} \boldsymbol{\beta})$ in (3.3) can be calculated at every observation of the sample, the average series is then generated and the result multiplied by $\boldsymbol{\beta}$. Greene (2000) p. 816 suggests that current practice favours the latter method, hence this is the method that we use to calculate marginal effects (slopes).

10 These surveys were financed by the European commissions PHARE ACE PROGRAMME 1997, Contract Number p97-8123-R.

${ }^{11}$ The small firm definition (10-49 employees) is in accord with the EU and also with recent Polish legislation (1999): "Law on Economic Activity".
} 
services were included in the population. The sampling technique used a proportionate stratification sampling method across the chosen sectors. Micro enterprises with less than 10 employees were not included since such data was not regarded as reliable. For the purpose of the model twenty-nine variables were chosen on both practical and theoretical grounds (based upon economic reasoning concerning their likely influences upon small firm's differential regional development) and are presented in Table 4. There were some variables for which accurate data was inherently difficult to obtain in small firm interviews (e.g. profit levels). We use 163 data points (74 firms from Pomorskie and 89 from Lubelskie).

\subsection{Potential Determinants of Regional Differences}

Economic theory indicted the choice and expected sign of the 29 variables chosen in our study. They are all expected to be positively correlated with the regional location of Pomorskie since this is the more dynamic and growing region (except the variable Trdunion, which can take either sign). These firms were expected to have more advanced legal status, greater networking experience (e.g. subcontracting), higher levels of technology, organization change of the firm and its products, greater levels of revenue, profits and wages, more foreign trade, investment and collaboration and to have higher levels of preparation for and expectation of gain from Europe. They were expected to use greater levels of franchising, credit, to have higher levels of training provision and the like. In general we expected that the more dynamic small firm would "choose" the Pomorskie region and that a group of significant variables would emerge indicating that a range of qualitative development characteristics of small firms would differentiate small firms between the two regions.

\subsection{Empirical results}

Table 1 reports the probit model estimation results. The general specification (Model 1) regresses the dependant variable on 29 explanatory variables taken from the original Polish firm survey. There is no evidence of heteroscedasticity, autocorrelation or nonnormally distributed residuals at the 5\% level of significance for any of the three models reported in Table 1, except for Model 1 where non-normality is evident. ${ }^{12}$ However, non-

\footnotetext{
${ }^{12}$ The test for heteroscedasticity is outlined in, for example, the E-Views User Guide pp. 421. It tests the null of homoscedasticity against the alternative that heteroscedasticity takes the form, $\sigma_{i}^{2}=\exp \left(2 \mathbf{z}_{i}^{\prime} \gamma\right)$, where $\mathbf{z}_{\mathrm{i}}$ is a vector of variables that the variance of the binary choice model, $\sigma_{\mathrm{i}}^{2}$, varies with and $\gamma$ is the corresponding coefficient vector. The auxiliary test equation is:

$\left\{\left(\mathrm{Y}_{\mathrm{i}}-\hat{\mathrm{P}}_{\mathrm{i}}\right) / \sqrt{ }\left[\hat{\mathrm{P}}_{\mathrm{i}}\left(1-\hat{\mathrm{P}}_{\mathrm{i}}\right)\right]\right\}=\left\{\phi(\mathbf{X} \boldsymbol{\beta}) / \sqrt{ }\left[\hat{\mathrm{P}}_{\mathrm{i}}\left(1-\hat{\mathrm{P}}_{\mathrm{i}}\right)\right]\right\} \mathbf{X} \boldsymbol{\delta}+\left\{\phi(\mathbf{X} \boldsymbol{\beta})(\mathbf{X} \boldsymbol{\beta}) / \sqrt{ }\left[\hat{\mathrm{P}}_{\mathrm{i}}\left(1-\hat{\mathrm{P}}_{\mathrm{i}}\right)\right]\right\} \mathbf{Z} \boldsymbol{\lambda}+\mathrm{v}_{\mathrm{i}}$

where $P_{i}$ denotes the fitted probability value and $\delta$ and $\lambda$ are coefficient vectors. The test statistic is the explained sum of squares of the above auxiliary regression which is distributed with degrees of freedom equal to the number of variables in the $\mathbf{Z}$ matrix (the matrix counterpart of vector $\mathbf{z}_{\mathbf{i}}$ ). In our application we use all of the variables in the $\mathbf{X}$ matrix, less the intercept, in the $\mathbf{Z}$ matrix. Thus the degrees of freedom are $\mathrm{k}^{\prime}=\mathrm{k}-1$, where $\mathrm{k}$ denotes the number of variables in the $\mathbf{X}$ matrix.
} 
normality is not evident at the $1 \%$ level for Model 1 suggesting that the departure from normality is not excessively severe and that the critical values employed for hypothesis testing will provide useful guidance. Further, because non-normality is not evident in the other models, inferences from these models will be valid.

In Model 1 five of the variables are statistically significant and feature the expected sign. However, because the other twenty-four variables are insignificantly different from zero (one cannot comment on their signs) we pursue model reduction to clarify the results and enhance efficiency of estimation. We employ the standard general-to-specific methodology by sequentially deleting the least significant variables (being reticent to exclude those that are regarded as most theoretically important) until we achieve a parsimonious specification. We obtain two different parsimonious models: Model 2 and Model 3.

The removal of 24 variables from Model 1 to yield Model 2 is valid according to an Ftest $[\mathrm{F}(1 \rightarrow)]$ at the $5 \%$ level (the probability value is 0.803 ). Model 2 incorporates 5 explanatory variables in addition to the intercept. They are the firm's legal status (Lstatus), the percentage of the firm's output that is subcontracted (Subcon) and whether the enterprise has introduced technologically improved goods (Newgoods). Also included are whether the firm intends to expand turnover (Turnover) and average gross wages (Avewage). ${ }^{13}$ All variables are statistically significant at the $5 \%$ level with $\mathrm{z}$-statistics greater than 1.96 in magnitude, except Lstatus which has a z-statistic of 1.921 (which is virtually significant). All five variables feature the expected positive correlation with the dependent variable. Model 2 explains $30.5 \%$ of the variation in the dependent variable and this explanatory power is statistically significant, according to the LR statistic, at the $5 \%$ level. ${ }^{14}$ The regression standard error is 0.412 which is approximately the average error of the model.

The removal of 25 variables from Model 1 to yield Model 3 is valid according to an Ftest $[\mathrm{F}(1 \rightarrow)]$ at the $5 \%$ level (the probability value is 0.616 ). Model 3 incorporates 4 explanatory variables in addition to the intercept, they are Subcon, Newgoods, Turnover and Avewage. All four variables feature the expected positive sign and are statistically significant at the 5\% level. Model 3 explains $28.8 \%$ of the variation in the dependent variable and this explanatory power is statistically significant, according to the LR statistic, at the $5 \%$ level. The regression standard error is 0.416 .

\footnotetext{
${ }^{13}$ A variable that looked insignificant (significant) in the general model becomes significant (insignificant) in the parsimonious model. This could arise because of improved efficiency from model reduction, for example. It is also worth noting that we do not simply exclude all insignificant variables in our model reduction process. We start by excluding all variables with z-ratios less than one then, once these have all been eliminated we exclude variables with z-ratios less than 1.5 and so on until we achieve a parsimonious model including only (near) significant variables.

${ }^{14}$ The pseudo $\mathrm{R}^{2}$ (or likelihood ratio index) is defined as: pseudo $\mathrm{R}^{2}=1-\left(\operatorname{lnL} / \ln \mathrm{L}_{0}\right)$, where $\ln \mathrm{L}$ and $\ln \mathrm{L}_{0}$ are the maximised values of the model's likelihood function including all variables and only incorporating an intercept, respectively - see Greene (2000, p 831). Clearly, if all the slope coefficients are zero then $\operatorname{lnL}$ equals $\ln \mathrm{L}_{0}$ and the pseudo $\mathrm{R}^{2}$ is zero. Perfect fit can only be obtained if $\operatorname{lnL}$ is zero (the likelihood function attaining the maximum value of one).
} 
In both Model 2 and Model 3 all of the retained variables' coefficients exhibit the expected positive sign, the exclusion restrictions are valid and there is no evident misspecification. Although all of the retained variables in Model 3 are individually significant, Model 2 has a better fit, a lower AIC (=1.031) and includes the additional variable Lstatus, which is almost significant. Hence we favour Model 2 for inference and argue that Lstatus may be considered an important explanatory factor of regional location in Poland. We therefore conclude that the variables that explain the regional location of Polish firms are as follows. The firm's legal status (Lstatus), the percentage of the firm's output that is subcontracted (Subcon), whether the enterprise has introduced technologically improved goods (Newgoods), whether the firm intends to expand turnover (Turnover) and average gross wages (Avewage).

To determine whether these inferences are robust to the different forms of binary choice model used we report the estimation results of Model 1 to 3 using the logit and gompit (extreme value) forms in tables 2 and 3, respectively. The inferences are qualitatively similar to those obtained for the probit formulation, reported in table 1. Although the coefficients are different for each model across the three forms of binary choice model, this is expected because the coefficients do not measure the marginal effects (slopes) of the variables. ${ }^{15}$ However, the slopes for each model across all three binary choice forms are virtually the same - except for the variable Qexport in the general specification, Model 1, which has a poorly determined coefficient. Hence, the results are robust across the three different types of binary choice model, which enhances our confidence in the inferences obtained.

\section{Explanation of the significant determinants of regional location}

Our significant variables indicate that a group of characteristics of small firms determine their location in Poland.

Those firms in our survey at the higher end of the free market development spectrum (e.g. more limited companies), tended to choose the more dynamic region to be located in. ${ }^{16}$ Firms that are legally structured as limited companies, for example, are more likely to survive, to raise finance ${ }^{17}$, to be larger in size, to be more specialised and technologically more advanced than sole traders. More advanced legal structures of small firms imply higher levels of corporate governance which are positively related to productivity levels of the small firm (Cowling 2003). Very importantly, higher actual and intended growth is expected of such companies. Storey (1994 p140) indicates that

\footnotetext{
${ }^{15}$ For example, Greene (2000) p. 817 suggests that one needs to multiply the coefficients on the probit model by the factor 1.6 to obtain values comparable to the logit form.

${ }^{16}$ The spectrum of legal ownership in our questionnaire was as follows: state owned enterprise, communal enterprise, co-operative, individual's business (sole enterprise), partnership, trade law partnership, joint stock, limited, other. The legal structure of a firm reflects other developmental levels of the firm.

${ }^{17}$ Freedman and Godwin $(1992,1994)$ in surveying the impact of limited liability on small firms concluded that its major benefit was in increased credibility with customers and banks (Storey 1994, p140).
} 
studies in the $\mathrm{UK}^{18}$.... "consistently point to more rapid growth ... by limited companies than by either sole proprietorships or partnerships". He indicates that this also applies to the relationship between limited liability status and companies' intentions to grow (Hakim 1989). The legal structure of a company is therefore indicative of a raft of structural features of small firms. While it is not new to point to the relationship between limited liability status and growth, the present study indicates that this exists at regional level. The firms with the more developed legal form "choose" (or are better able to survive) the more dynamic region.

Subcontracting proved a significant explanatory variable of the location of small firms. In the survey, Pomorskie's small firms engaged in seven times more subcontracting than Lubelskie's. This variable is indicative of a range of behavioral features. The firm that is subcontracting is clearly more networked and connected than a firm that is not. Such a firm is knowledgeable about the "rules of engagement" with larger firms, including foreign enterprises. This firm will be more advanced in information technology and has access to more contracts than other less "connected" firms. Its knowledge of quality working practices will be more advanced and it can work as part of a team. Many such firms are part of a cluster arrangement and its associated benefits (Schmitz 1992). It will be more flexible and responsive to change than other firms. It is also likely to have more credit accessible to it since the more a firm is part of a cluster of interrelated firms that "know" one another the more likely such a firm is to receive trade credit, or obtain references for bank credit. Such connectivity and transparency is not available to the more isolated firm which will have far more limited and expensive forms of credit available. Since credit is a general constraint on small firm development in Poland (as well as many other countries) then sub-contracting is indicative of ways of overcoming this problem (Petersen and Rajan 1997). Subcontracting has not been traditionally stressed in the small firm literature. Indeed earlier studies (Lyons 1991) had pointed to the dependency and vulnerability of subcontractors vis-à-vis large firms. Nevertheless it has become a more important policy tool and the EU has developed special arrangements to harmonize subcontracting relations. Certain countries (France and Holland), in this knowledge developed early special laws and programs on subcontracting in order to help smaller firms (Storey 1994 p301). In the case of Poland, with a significant FDI input into the economy the issue is more vital. Pomorskie has considerably more FDI than Lubelskie due to its geographical location and comparative economic dynamism. Subcontracting arrangements by national smaller firms with foreign companies becomes a matter of strategic importance and competitive advantage in such a region.

The significant performance variables of this study - the introduction of technologically improved goods, the higher average wage and the intention to expand turnover - indicate that more advanced firms tended to choose the more dynamic region. A higher technological level of a small firm's products indicates greater productivity advances. ${ }^{19}$

\footnotetext{
${ }^{18}$ Storey (1994, p140) quotes Kallenberg and Leicht (1991) and Reynolds and Miller (1988) who show the same relationship between limited liability and growth for the US.

${ }^{19}$ See Acs and Audretsch (1990) and Carlsson (1991) for the capacity of small firms to capture market share through productivity and innovation advances.
} 
Other studies also indicate a clear correlation between small firm growth and new product development (Wo et al.1989, Dunkelberg et al. 1987, Solem and Steiner 1989, Wynarczyk et al. 1993). The higher average wage of small firms is theoretically expected to be correlated with a higher marginal productivity of labour, ${ }^{20}$ while the intention to expand turnover indicates the existence of higher profit levels. ${ }^{21}$ Productivity, profit and growth differentials between the small firms is explanatory of their regional choice of location. The more dynamic firms can flourish/survive in the faster growing region.

Many, though not all, of the above mentioned variables that proved significant in our study have also occurred in other studies of small firm growth. Some of these have been referred to in the text. However our study differs from these in that it shows how they are linked with regional choice of location. The purpose of this paper was to test this relationship rather than presume it. Moreover the sparse literature on small firms and regions makes no reference to this relationship.

\section{Policy and Theory Implications}

This paper develops a link between small firm development and the choice of regional location in a transitional economy.

Implications and limitations of this research include the following. Firstly, since our two regions are representative of regional polarization in Poland we believe that our results can be extended to the rest of the country. Ideally further research on small firm qualitative development differences in various regions could provide the data for this. In practice such data on qualitative functioning of small firms anywhere in the world is rare. Secondly, the principle that small firms of differing developmental levels choose regions of differing dynamism has theoretical and policy implications. ${ }^{22}$ Theoretically there is an absence in the regional and small firm literature of an awareness of this relationship and both fields could benefit by its further testing and potential incorporation into the literature. With respect to policy our results add to the traditional policy orientation of support to flagging regions by showing how firms will naturally augment a process of regional development. More developed firms will tend to choose to locate (or stay) in faster developing regions where their potential can be realized - or be more able to survive. As implied by cumulative causation theory this process can be self-sustaining. Out paper shows a link in this process.

\footnotetext{
${ }^{20}$ In economic theory the real wage is equal to the marginal product of labour in order for profit to be maximised. In the Cobb-Douglas framework also wage growth and profits are linked to productivity growth (McCann 2001 p241-2).

21 "Intentionality" is linked to past and future performance - the intention to increase output is correlated with recent past growth on the one hand and also to actual subsequent growth performance (Pistrui et alia 2002, Ghatak et al. 2003).

${ }^{22}$ We must beware of extending these results outside of Poland to other transitional economies without further investigation. Poland is more advanced than many other central and Eastern European countries in its transition to a market economy and is therefore at a different developmental level.
} 


\section{Conclusion}

The literature on Polish regions and small firms has noted the comparatively underpowered small firm stratum on the one hand and regional disparities on the other. Until now there has been no statistical or econometric work examining qualitative differences between small firms in the Polish regions. This paper stresses the seriousness of Polish regional polarization and chooses two regions as representative of this process. With reference to a unique database it probes into qualitative characteristics of the small firm stratum in these two representative regions and econometrically tests for explanatory variables of regional location. We locate our investigation in the context of cumulative causation theory and a Penrosian perspective of the organizational importance of a firm's functioning. Thus we argue that the more dynamic region is "chosen" by the more developed small firm (illustrated by structural, behavioral and conduct features) which finds greater opportunity for the realization of profits, sales and growth, in the faster growing regions. More developed firms are also more able to survive in such a region than less developed firms. Our econometric results indicates that five variables are significant: the firm's legal status, the percentage of the firm's output that is subcontracted, whether the enterprise has introduced technologically improved goods, and whether the firm intends to expand turnover and average gross wages. 


\section{APPENDIX}

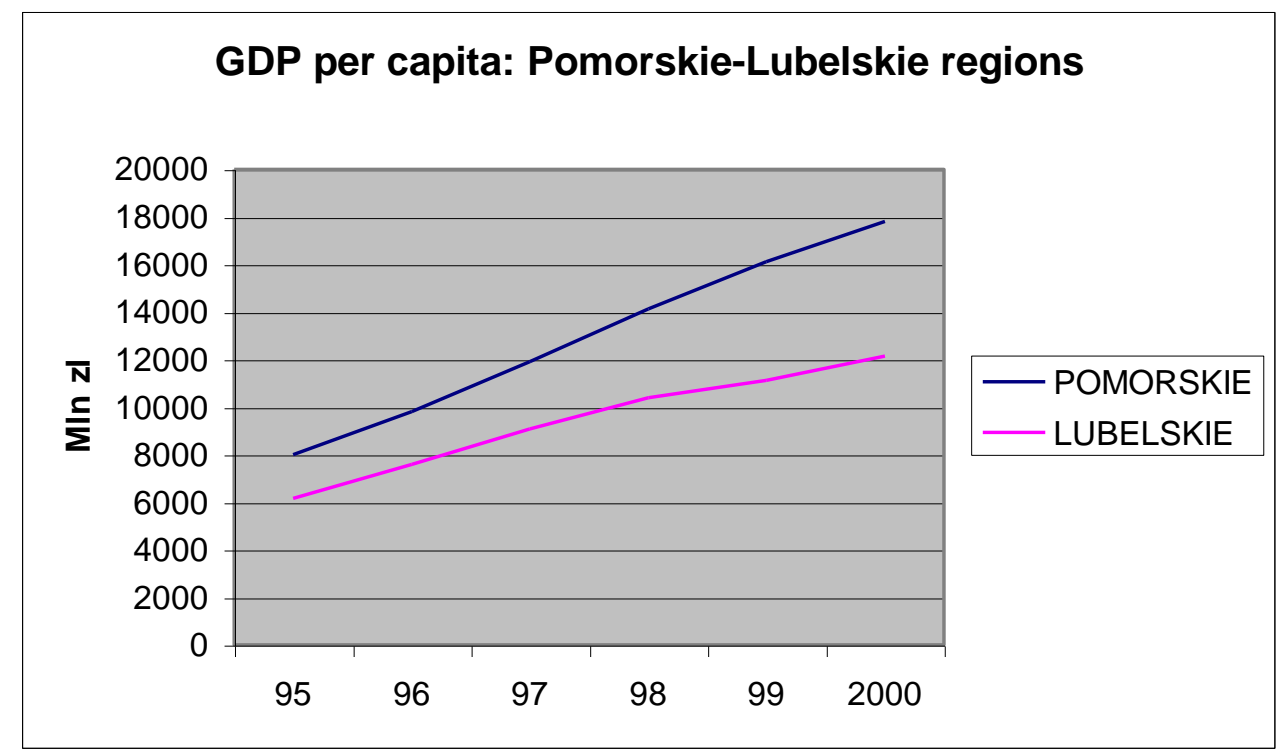

Fig 1. Source Authors' calculations from GUS data base.

Polska Statystyka Publiczn http://www.stat.gov.pl/english 


\section{References.}

Acs Z. and Audretsch D. 1990. "Small Firms in US Manufacturing: A First Report", Economic Letters, 31(4), pp. 399-402.

Amable, B. 1993. "Catch-up and Convergence in a Model of Cumulative Growth." International Review of Applied Economics, 7: 1-25.

Berger K., Chmiel J., Pawlowska Z., Zienkowski L. 1998. Contribution of SMEs to the Development of the Polish Economy. Research Centre for Economic and Statistical Studies. Central Statistical Office and Polish Academy of Sciences. Warsaw

Braczyk H. J., Cooke P,. Heidenreich M. Regional innovation systems : the role of governances in a globalized world London; Bristol, Pa., USA : UCL Press, 1998

Carlsson, B., 1991, 'The Re-emergence of Small-Scale Production: An International Perspective'. Small Business Economics, 3(1), 1-38.

Cowling M., 2003. "Productivity and Corporate Governance in Smaller Firms" Small Business Economics 20 (4): 335-344, June 2003. Kluwer.

De Benedictis, L. (1998). “Cumulative Causation, Harrod's Trade Multiplier, and Kaldor's Paradox: Foundations of Post-Keynesian Theory of Growth Differentials." In: Economic Dynamics, Trade and Growth: Essays on Harrodian Themes. G. Rampa, L. Stella and A.P. Thirlwall (eds.). Basingstoke: Macmillan.

Dixon R.J and Thirlwall A.P. 1975. "A Model of Regional Growth Rate Differentials along Kaldorian Lines." Oxford Economic Papers, 27, 201-14.

Dunkelberg W.G, Cooper A.C. Woo C, and Dennis W.J. 1987, "New firm Growth and Performance" In N.C.Churchill et al. Frontiers of Entrepreurship Research, Babson College. Boston Mass.

Dzierzanowski W., Stachowiak M., (Eds) 2001. Report on the Condition of the SME Sector in Poland for the Years 1999-2000. Polish Agency for Enterprise Development. Warsaw 2001

E-Views 4.0 User's Guide, Quantitative Micro Software, 2000.

Freedman J.and Godwin M. (1992). "Incorporating the Micro Business: in K.Caley et al. Small Enterprise Development: Policy and Practice in Action. Paul Chapman Publishing, London.

Fingleton, B. and McCombie, J.S.L. 1998. "Increasing Returns and Economic Growth: Some New Evidence From Manufacturing from the European Union Regions." Oxford Economic Papers, 50: 89-105. 
Ghatak S. Mulhern A. Stewart C. 2003. "Determinants of Intended Expansion of Polish Small Firms". Journal of Policy Modeling. 25, 287-296.

Greene William H: "Econometric Analysis”. Prentice Hall, 4 ${ }^{\text {th }}$ edition, 2000.

Hakim C. (1989). "Identifying Fast Growth Small Firms" Employment Gazette, Jan. pp29-41.

Hirschman A. 1958. The Strategy of Economic Development. London Constable.

Jovanovic B. 1982. "Selection and Evolution of Industry". Econometrica 50, 508-523

Kaldor N. 1970. "The Case for Regional Policies". Scottish Journal of Political Economy, 18, 337-48.

Lyons B.R. (1991). "Subcontracting and the Small Business". End of Award Report, ESRC, Swindon, UK.

Mitra A. 2002. "Total Factor Productivity Growth and Urbanization Economies: A Case of Indian Industries". Review of Urban \& Regional Development Studies. Vol. 12: 2.

Myrdal G. 1957. Economic Theory and the Underdeveloped Regions. London Duckworth.

McCann P. 2001. Urban and Regional Economics. Oxford University Press.

Mulhern A. 2003. "Identifying Growth Characteristics in the Polish Small Firm Stratum". Economics Discussion Papers 2003/10. Economics Department., Kingston University.

Piasecka E. and Rainnie A. 2000. "Small Firms and Local Economic Development in Poland: Limits and Possibilities". Journal of Southern Europe and the Balkans. Vol 2 No.1.

Piasecki B., Rogut A., Smallbone D. 2000. Polish SMEs in the Context of European Single Market. Polish Foundation for Small and Medium Enterprise Promotion and Development. Lodz.

Penrose E. T. 1959. The Theory of the Growth of the Firm. Oxford. Blackwell

Petersen M. and Rajan P. 1997. "Trade Credit: Theories and Evidence". The Review of Financial Studies. Vol. 10. No.3. pp.661-691.

The Polish Agency for Enterprise Development 2001. Report on the Condition of the Small and Medium Size Enterprise Sector in Poland for the Years 1999-2000. Polska 
Agencja Rozwoju Przedsiebiorczosci. ISBN 83-88802-20-8. Naj-Comp, ul. Majdanska $4 \mathrm{~m}$ 48, 04-088 Warsaw.

Polish Statistics: Polska Statystyka Publiczn http://www.stat.gov.pl/english.

Reynolds P.D. and Miller B. (1988). "1988 Minnesota New Firms Study: an Exploration of New firms and their Economic Contributions". Centre for Urban and Regional Affairs, Minneapolis, Minnesota.

Smallbone D., Piasecki B., Rogut A., Venesaar U., Rumpis. and Budreikate D., 1996 "The Survival, Growth and Support needs of Manufacturing SMEs in Poland and the Baltic States". Centre For Enterprise and Economic Development Research. Middlesex University. London. UK.

Smallbone D., Piasecki B., Rogut A., 2001 "The Implications of EU Accession for Polish SMEs. Environment and Planning C: Government and Policy", vol 19. Pp. 317-333.

Schmitz H. 1992. "On the Clustering of Small Firms". IDS Bulletin Vol 23 pp64-69.

Solem O. and Steiner M.P. 1989. "Factors for Success in Small Manufacturing Firms and special Emphasis on Growing Firms". Conference paper Small and Medium size Enterprises and the Challenges of 1992, Mikkeli Finland.

Szreder M., 2001 "Development of Small Enterprises in Poland. Results of a sample survey conducted in the Province of Gdansk." Statistics in Transition: Journal of the Polish Statistical Association vol. 5, No.1, March

Storey (1994). Understanding the Small Business Sector. Routledge.

Wo Dunkelberg W.G, Cooper A.C Dallenbach U. and Dennis W.J. 1989, "Determinants of Growth for small and large Entrepreneurial Start-Ups". Conference paper at Babson Entrepreneurship Conference

Woodward, R.: 2001, SME support in post-communist countries: moving from individual to cooperative approaches (reflections on the Polish case), MOCT-MOST.

Wynarczyk P. Watson R. Storey D.J. Short H. Keasey K. 1993. The Managerial Labour Market in Small and Medium size Enterprises. Routledge London. 
Table 1: Probit Regional Differences Regressions

\begin{tabular}{|c|c|c|c|c|c|c|c|c|c|}
\hline & \multicolumn{3}{|c|}{ Model 1} & \multicolumn{3}{|c|}{ Model 2} & \multicolumn{3}{|c|}{ Model 3} \\
\hline Variable & Coef & z-stat & Slope & Coef & z-stat & Slope & Coef & z-stat & Slope \\
\hline Intercept & -6.834 & -2.871 & - & -6.211 & -5.658 & - & -4.931 & $\begin{array}{l}-6.039 \\
\end{array}$ & - \\
\hline Lstatus & 0.343 & 2.107 & 0.081 & 0.249 & 1.921 & 0.067 & & & \\
\hline Sector & -0.079 & -0.097 & -0.019 & & & & & & \\
\hline Fcapital & 0.007 & 0.545 & 0.002 & & & & & & \\
\hline Subcon & 0.021 & 2.974 & 0.005 & 0.015 & 3.360 & 0.004 & 0.015 & 3.348 & 0.004 \\
\hline Qothereg & -0.005 & -0.901 & -0.001 & & & & & & \\
\hline Qexport & 0.001 & 0.0767 & 0.0001 & & & & & & \\
\hline Franchis & 0.210 & 0.224 & 0.050 & & & & & & \\
\hline Demand & -0.220 & -0.503 & -0.052 & & & & & & \\
\hline Comp & -0.372 & -0.510 & -0.088 & & & & & & \\
\hline Techprod & 0.398 & 1.010 & 0.094 & & & & & & \\
\hline Internet & -0.182 & -0.456 & -0.043 & & & & & & \\
\hline Newgoods & 1.477 & 3.349 & 0.350 & 0.683 & 2.896 & 0.183 & 0.648 & 2.785 & 0.178 \\
\hline Newmethd & 1.062 & 2.309 & 0.251 & & & & & & \\
\hline Neworg & 0.676 & 1.531 & 0.160 & & & & & & \\
\hline Newprop & 1.713 & 1.242 & 0.405 & & & & & & \\
\hline Exsupprt & -1.131 & -1.005 & -0.268 & & & & & & \\
\hline Farise & -0.195 & -0.648 & -0.046 & & & & & & \\
\hline Turnover & 0.122 & 1.090 & 0.029 & 0.183 & 2.816 & 0.049 & 0.205 & 3.049 & 0.056 \\
\hline Employed & 0.009 & 0.473 & 0.002 & & & & & & \\
\hline Empgrow & 0.002 & 0.374 & 0.0004 & & & & & & \\
\hline Humcap & -0.269 & -0.678 & -0.064 & & & & & & \\
\hline Avewage & 0.003 & 3.943 & 0.001 & 0.003 & 5.255 & 0.001 & 0.003 & 5.253 & 0.001 \\
\hline Trdunion & 0.369 & 0.333 & 0.087 & & & & & & \\
\hline Euaffect & 0.071 & 0.258 & 0.017 & & & & & & \\
\hline Eupreprn & 0.216 & 0.509 & 0.051 & & & & & & \\
\hline Loan2yrs & -0.496 & -1.727 & -0.117 & & & & & & \\
\hline Revenuef & 0.077 & 0.509 & 0.018 & & & & & & \\
\hline Prgrow98 & 0.004 & 0.862 & 0.001 & & & & & & \\
\hline Profityr & -0.304 & $\begin{array}{l}-1.179 \\
\end{array}$ & -0.072 & & & & & & \\
\hline \multicolumn{10}{|l|}{ Summary } \\
\hline $\operatorname{Avg}[\phi(\mathbf{X} \boldsymbol{\beta})]$ & & & 0.236 & & & 0.268 & & & 0.275 \\
\hline Fit & Stat & Prob & & Stat & Prob & & Stat & Prob & \\
\hline $\mathrm{R}^{2}$ & 0.386 & & & 0.305 & & & 0.288 & & \\
\hline $\mathrm{S}$ & 0.420 & & & 0.412 & & & 0.416 & & \\
\hline AIC & 1.215 & & & 1.031 & & & 1.042 & & \\
\hline LR Statistic & 86.600 & 0.000 & & 68.569 & 0.000 & & 64.688 & 0.000 & \\
\hline $\mathrm{F}(1 \rightarrow)$ & & & & 0.739 & 0.803 & & 0.891 & 0.616 & \\
\hline Misspec & Stat & Prob & & Stat & Prob & & Stat & Prob & \\
\hline$\chi^{2}\left(\mathrm{H}, \mathrm{k}^{\prime}\right)$ & 16.805 & 0.965 & & 3.679 & 0.596 & & 4.184 & 0.382 & \\
\hline$\chi^{2}(\mathrm{~A}, 1)$ & 0.207 & 0.649 & & 0.002 & 0.967 & & 0.069 & 0.793 & \\
\hline$\chi^{2}(\mathrm{~N}, 2)$ & 8.790 & 0.012 & & 1.371 & 0.504 & & 1.003 & 0.606 & \\
\hline
\end{tabular}

$\operatorname{Avg}[\phi(\mathbf{X} \boldsymbol{\beta})]$ is the average value of the $\phi(\mathbf{X} \boldsymbol{\beta})$ series - the latter is calculated at the estimated value of $\boldsymbol{\beta}$ for each observation - which is employed in the calculation of the slope $\{$ slope $=\boldsymbol{\beta} \times \operatorname{Avg}[\phi(\mathbf{X} \boldsymbol{\beta})]\} . \mathrm{R}^{2}$ is the McFadden $\mathrm{R}^{2}$ and $\mathrm{F}(1 \rightarrow)$ denotes the F-test for the exclusion of variables from model 1 to obtain the specified restricted form. $\chi^{2}\left(\mathrm{H}, \mathrm{k}^{\prime}\right)$ is a test for heteroscedasticity (see E-Views 4 User's Guide pp. 421-422) which is distributed with k' degrees of freedom, where $\mathrm{k}^{\prime}$ is the number of variables in the estimated binary choice model excluding the intercept (model 1: $\mathrm{k}^{\prime}=29$; model 2: $\mathrm{k}^{\prime}=5$; model 3: $\left.\mathrm{k}^{\prime}=4\right) \cdot \chi^{2}(\mathrm{~A}, 1)$ is the Ljung-Box test for first-order autocorrelation and $\chi^{2}(\mathrm{~N}, 2)$ denotes the Jarque-Bera test for non-normally distributed residuals. All estimations were carried out using Eviews 4.1. 
Table 2: Logit Regional Differences Regressions

\begin{tabular}{|c|c|c|c|c|c|c|c|c|c|}
\hline & \multicolumn{3}{|c|}{ Model 1 } & \multicolumn{3}{|c|}{ Model 2} & \multicolumn{3}{|c|}{ Model 3} \\
\hline Variable & Coef & z-stat & Slope & Coef & z-stat & Slope & Coef & z-stat & Slope \\
\hline Intercept & -11.857 & -2.805 & - & -10.474 & -5.296 & - & -8.272 & -5.548 & - \\
\hline Lstatus & 0.591 & 2.053 & 0.083 & 0.440 & 1.939 & 0.070 & & & \\
\hline Sector & -0.173 & -0.119 & -0.024 & & & & & & \\
\hline Fcapital & 0.013 & 0.561 & 0.002 & & & & & & \\
\hline Subcon & 0.036 & 2.930 & 0.005 & 0.025 & 3.236 & 0.004 & 0.025 & 3.233 & 0.004 \\
\hline Qothereg & -0.009 & -0.903 & -0.001 & & & & & & \\
\hline Qexport & -0.0001 & -0.007 & -1.172 & & & & & & \\
\hline Franchis & 0.367 & 0.232 & 0.052 & & & & & & \\
\hline Demand & -0.292 & -0.379 & -0.041 & & & & & & \\
\hline Comp & -0.525 & -0.422 & -0.074 & & & & & & \\
\hline Techprod & 0.706 & 1.059 & 0.099 & & & & & & \\
\hline Internet & -0.279 & -0.412 & -0.039 & & & & & & \\
\hline Newgoods & 2.503 & 3.231 & 0.352 & 1.164 & 2.870 & 0.186 & 1.062 & 2.691 & 0.175 \\
\hline Newmethd & 1.847 & 2.303 & 0.260 & & & & & & \\
\hline Neworg & 1.167 & 1.510 & 0.164 & & & & & & \\
\hline Newprop & 2.962 & 1.295 & 0.417 & & & & & & \\
\hline Exsupprt & -1.907 & -1.017 & -0.268 & & & & & & \\
\hline Farise & -0.350 & -0.665 & -0.049 & & & & & & \\
\hline Turnover & 0.206 & 1.100 & 0.029 & 0.306 & 2.836 & 0.049 & 0.335 & 3.047 & 0.055 \\
\hline Employed & 0.014 & 0.436 & 0.002 & & & & & & \\
\hline Empgrow & 0.003 & 0.415 & 0.0004 & & & & & & \\
\hline Humcap & -0.496 & -0.731 & -0.070 & & & & & & \\
\hline Avewage & 0.006 & 3.781 & 0.001 & 0.005 & 4.946 & 0.001 & 0.005 & 4.871 & 0.001 \\
\hline Trdunion & 0.679 & 0.359 & 0.013 & & & & & & \\
\hline Euaffect & 0.092 & 0.195 & 0.013 & & & & & & \\
\hline Eupreprn & 0.315 & 0.421 & 0.044 & & & & & & \\
\hline Loan2yrs & -0.842 & -1.723 & -0.118 & & & & & & \\
\hline Revenuef & 0.149 & 0.584 & 0.021 & & & & & & \\
\hline Prgrow98 & 0.007 & 0.842 & 0.001 & & & & & & \\
\hline Profityr & -0.507 & -1.147 & -0.071 & & & & & & \\
\hline \multicolumn{10}{|l|}{ Summary } \\
\hline $\operatorname{Avg}[\phi(\mathbf{X} \boldsymbol{\beta})]$ & & & 0.141 & & & 0.160 & & & 0.165 \\
\hline Fit & Stat & Prob & & Stat & Prob & & Stat & Prob & \\
\hline $\mathrm{R}^{2}$ & 0.382 & & & 0.302 & & & 0.284 & & \\
\hline $\mathrm{s}$ & 0.420 & & & 0.416 & & & 0.417 & & \\
\hline AIC & 1.220 & & & 1.036 & & & 1.047 & & \\
\hline LR Statistic & 85.758 & 0.000 & & 67.756 & 0.000 & & 63.861 & 0.000 & \\
\hline $\mathrm{F}(1 \rightarrow)$ & & & & 0.746 & 0.796 & & 0.741 & 0.595 & \\
\hline Misspec & Stat & Prob & & Stat & Prob & & Stat & Prob & \\
\hline$\chi^{2}\left(\mathrm{H}, \mathrm{k}^{\prime}\right)$ & 18.160 & 0.941 & & 3.742 & 0.587 & & 4.021 & 0.403 & \\
\hline$\chi^{2}(\mathrm{~A}, 1)$ & 0.188 & 0.665 & & 0.001 & 0.977 & & 0.084 & 0.772 & \\
\hline$\chi^{2}(\mathrm{~N}, 2)$ & 12.607 & 0.002 & & 1.637 & 0.441 & & 0.600 & 0.741 & \\
\hline
\end{tabular}

All statistics are the same as in Table 1 except $\operatorname{Avg}[\phi(\mathbf{X} \boldsymbol{\beta})]$ employs the logistic distribution rather than the normal distribution. 
Table 3: Gompit (Extreme Value) Regional Differences Regressions

\begin{tabular}{|c|c|c|c|c|c|c|c|c|c|}
\hline & \multicolumn{3}{|c|}{ Model 1} & \multicolumn{3}{|c|}{ Model 2} & \multicolumn{3}{|c|}{ Model 3} \\
\hline Variable & Coef & z-stat & Slope & Coef & z-stat & Slope & Coef & z-stat & Slope \\
\hline Intercept & -6.935 & -2.628 & - & -6.182 & -5.179 & - & -4.993 & -5.772 & - \\
\hline Lstatus & 0.417 & 2.026 & 0.086 & 0.246 & 1.621 & 0.058 & & & \\
\hline Sector & -0.027 & -0.033 & -0.006 & & & & & & \\
\hline Fcapital & 0.006 & 0.419 & 0.001 & & & & & & \\
\hline Subcon & 0.022 & 2.628 & 0.005 & 0.017 & 3.070 & 0.004 & 0.017 & 3.131 & 0.004 \\
\hline Qothereg & -0.003 & -0.471 & -0.001 & & & & & & \\
\hline Qexport & -0.001 & -0.107 & -0.0002 & & & & & & \\
\hline Franchis & 0.251 & 0.270 & 0.052 & & & & & & \\
\hline Demand & -0.396 & -0.846 & -0.082 & & & & & & \\
\hline Comp & -0.491 & -0.624 & -0.102 & & & & & & \\
\hline Techprod & 0.517 & 1.142 & 0.107 & & & & & & \\
\hline Internet & -0.275 & $\begin{array}{l}-0.560 \\
\end{array}$ & -0.057 & & & & & & \\
\hline Newgoods & 1.505 & 2.988 & 0.312 & 0.750 & 2.839 & 0.177 & 0.703 & 2.686 & 0.168 \\
\hline Newmethd & 0.960 & 1.829 & 0.199 & & & & & & \\
\hline Neworg & 0.676 & 1.399 & 0.140 & & & & & & \\
\hline Newprop & 1.652 & 1.048 & 0.342 & & & & & & \\
\hline Exsupprt & -1.274 & -1.038 & -0.264 & & & & & & \\
\hline Farise & -0.227 & -0.669 & -0.047 & & & & & & \\
\hline Turnover & 0.131 & 0.983 & 0.027 & 0.187 & 2.673 & 0.044 & 0.209 & 2.854 & 0.050 \\
\hline Employed & 0.016 & 0.631 & 0.003 & & & & & & \\
\hline Empgrow & 0.001 & 0.161 & 0.0002 & & & & & & \\
\hline Humcap & -0.270 & -0.570 & -0.056 & & & & & & \\
\hline Avewage & 0.004 & 3.676 & 0.001 & 0.003 & 5.290 & 0.001 & 0.003 & 5.316 & 0.001 \\
\hline Trdunion & 0.091 & 0.068 & 0.014 & & & & & & \\
\hline Euaffect & 0.069 & 0.216 & 0.014 & & & & & & \\
\hline Eupreprn & 0.316 & 0.686 & 0.065 & & & & & & \\
\hline Loan2yrs & -0.518 & -1.588 & -0.107 & & & & & & \\
\hline Revenuef & 0.073 & 0.411 & 0.015 & & & & & & \\
\hline Prgrow98 & 0.006 & 0.925 & 0.001 & & & & & & \\
\hline Profityr & -0.417 & -1.206 & -0.086 & & & & & & \\
\hline \multicolumn{10}{|l|}{ Summary } \\
\hline $\operatorname{Avg}[\phi(\mathbf{X} \boldsymbol{\beta})]$ & & & 0.207 & & & 0.236 & & & 0.239 \\
\hline Fit & Stat & Prob & & Stat & Prob & & Stat & Prob & \\
\hline $\mathrm{R}^{2}$ & 0.381 & & & 0.304 & & & 0.292 & & \\
\hline $\mathrm{s}$ & 0.422 & & & 0.413 & & & 0.417 & & \\
\hline AIC & 1.221 & & & 1.032 & & & 1.037 & & \\
\hline LR Statistic & 85.556 & 0.000 & & 68.302 & 0.000 & & 65.489 & 0.000 & \\
\hline $\mathrm{F}(1 \rightarrow)$ & & & & 0.731 & 0.812 & & 0.851 & 0.671 & \\
\hline Misspec & Stat & Prob & & Stat & Prob & & Stat & Prob & \\
\hline$\chi^{2}\left(\mathrm{H}, \mathrm{k}^{\prime}\right)$ & 31.712 & 0.333 & & 4.253 & 0.514 & & 2.508 & 0.643 & \\
\hline$\chi^{2}(\mathrm{~A}, 1)$ & 0.147 & 0.701 & & 0.053 & 0.818 & & 0.225 & 0.635 & \\
\hline$\chi^{2}(\mathrm{~N}, 2)$ & 2.346 & 0.309 & & 0.896 & 0.639 & & 0.110 & 0.946 & \\
\hline
\end{tabular}

All statistics are the same as in Table 1 except $\operatorname{Avg}[\phi(\mathbf{X} \boldsymbol{\beta})]$ employs the Type-I extreme value distribution rather than the normal distribution. The test for heteroscedasticity for Model 1 uses 159, rather than 163, observations. This is because four of the fitted probabilities from this model equal zero which means that the denominator of the scaling factor used in the auxiliary test regression was also zero. Thus, for these four observations the variables in the auxiliary regression could not be calculated and so were excluded. 
Table 4. Full Name of Variables

\begin{tabular}{|ll|}
\hline Legal status of firm & Lstatus \\
Public or private sector of economy & Sector \\
Ownership of other foreign firms & Fcapital \\
Subcontracting activity & Subcon \\
Export to other Polish regions & Qothereg \\
Export abroad & Qexport \\
Franchising activity & Franchis \\
Adequacy of level of demand & Demand \\
Foreign firms as the major competitors & Comp \\
Technological level of firm's products & Techprod \\
Internet use & Internet \\
New goods produced in last two years & Newgoods \\
New methods of production in the last two years & Newmethd \\
New organizational forms in last two years & Neworg \\
New business premises in last two years & Newprop \\
External financial support & Exsupprt \\
Increase in fixed assets 1998-99 & Farise \\
Intention to increase turnover & Turnover \\
Numbers employed in the firm in 1999 & Employed \\
Percentage increase in employment 1998-99. & Empgrow \\
Policy on human capital development & Humcap \\
Level of average wage in the firm & Avewage \\
Absence of trade unions in the firm & Trdunion \\
Optimism of EU accession upon the firm & Euaffect \\
Preparation for the EU & Eupreprn \\
Existence of a bank loan in 1988-99 & Loan2yrs \\
Revenue level in 1999 & Revenuef \\
Proportionate change in profits from 1997 to 1998 & Prgrow98 \\
Number of years of positive profits & Profityr \\
\hline
\end{tabular}

